\title{
The Centrality of Brand Awareness
}

\author{
Michael Adiwijaya $^{1 *}$, Erin McGuinness ${ }^{2}$, John C Cary ${ }^{2}$, Halimin Herjanto ${ }^{3}$ \\ ${ }^{1}$ Petra Christian University, Jl. Siwalankerto No. 121-131, Surabaya, Indonesia \\ ${ }^{2}$ Marist College, 3399 North Road, Poughkeepsie, NY 12601. U.S.A \\ ${ }^{3}$ University of the Incarnate Word, 4301 Broadway, San Antonio, TX 78209. U.S.A \\ Email: 1“michaels@petra.ac.id; ${ }^{2}$ erin.mcguin@gmail.com; ${ }^{2}$ john.cary@ marist.edu; ${ }^{3}$ herjanto@uiwtx.edu \\ "Corresponding author
}

\begin{abstract}
The brand concept, especially brand loyalty, has evolved significantly; however, this phenomenon is still considered far from complete. This study extends a long line of scholars' efforts by investigating a moderating effect of brand awareness in triangle relationships between product innovation and brand trust and brand loyalty. The hypotheses were tested based on online questionnaire data collected from 100 Indonesian respondents. The Ordinary least square (OLS) regression analysis shows that brand awareness positively and significantly moderates these triangle relationships. Additionally, the direct relationships between product innovation on brand awareness and brand loyalty and brand trust and brand loyalty were found to be significant. This research offers future research direction and implications for business practitioners and academics.
\end{abstract}

Keywords: Product Innovation; Brand Awareness; Brand Trust; Brand Loyalty.

\section{Introduction}

"Brand awareness is the fuel that keeps new leads coming into your business so that ultimately you can convert them into customers and hopefully brand ambassadors", said Slisha Kankariya (Co-founder of with Clarity).

During the 2020 U.S. presidential campaign, Andrew Yang, the presidential candidate from the Democrat Party warned the U.S. public and businesses of the impact of the fourth industrial revolution. During his interview with the New York Times editorial board, Mr. Yang suggested that the fourth industrial revolution would change the rules of the game and increase competition in every division of the economy and industry (The Editorial Board, 2019). As the globe is now entering the fourth industrial revolution, business competitiveness has increased significantly. For example, Professor Christensen, a Harvard Business School Professor, suggested that a decade ago, on average, American businesses introduced about 30,000 product innovations to the market (Morin, 2020); however, Stebbins (2020) suggests that in 2019, American companies launched countless new product innovations with the combined worth of $\$ 14.7$ trillion.

Although product innovation is believed to improve businesses' competitiveness, growth, and profitability (Freixanet \& Churakova, 2018), scholars and business practitioners are aware that product innovation is very risky (Shin et al., 2019) and has an $80 \%$ failure rate (Malgarejo \& Malek, 2018). According to Malgarejo \& Malek's report (2018), only 5\% of such product innovation managed to appeal to customers, and this low success rate is determined by how a brand demonstrates appeal and shows innovativeness to their customers. Existing literature shows that a brand is a unique identifier that serves as a product's performance barometer (Puspitasari \& Dwijayanti, 2019) that helps distinguish and protect businesses from their competitors introducing product innovation (Putra \& Razi, 2020). Further, He et al. (2017) suggest that brand appeal facilitates brand communication efforts that improve customer experience. Accordingly, such a positive experience increases the customer's ability to visualize and internalize the product, strengthening brand awareness.

Brand awareness is claimed as one of the most critical dimensions in brand strategy (Pribadi et al., 2019; Setiadi et al., 2018). This claim is because brand awareness creates stronger brand memory (Razak et al., 2019) and creates a closer association or connection with customers (Vasudevan \& Kumar, 2019). In addition, brand awareness is responsible for improving brand equity, brand power (Lee, 2018), and brand loyalty (Pribadi et al., 2019). In different studies, brand awareness has been found to play an essential moderating role in various relationships. For example, Raimondo et al. (2019) Italian study revealed that brand awareness strongly moderates 
the relationship between abstract information and customer product evaluation.

Similarly, Uribe-Saavedra et al. (2015) Spanish study found that brand awareness moderates the relationship between online comments and buying intention. Recently, Yigit \& Tigli's (2018) Turkish study also documented that brand awareness moderates the relationship between time pressure, perceived risk, online browsing, and online impulsive buying behavior. These findings conclude that brand awareness plays a crucial role in building a more substantial brand presence and may affect customerpurchasing behavior. Thus, as stated by Slisha Kankariya's quote above, brand awareness is key to building customer loyalty and business success.

Although the findings above establish a strong basis of fundamental knowledge of brand awareness, Mihn et al. (2015) suggest that the results are mixed and inconclusive and warrant further investigation. Firstly, despite many studies investigating the moderating role of brand awareness, these studies concentrate their investigation on different relationships while an investigation on product innovation does not exist. For example, Wang \& Yang (2010) investigate the influence of brand awareness on the relationship between brand credibility and purchase intention. Liu \& Huang (2015) explore the effect of brand awareness on the link between distribution effectiveness and consumer heart share. Lemmetyinen et al. (2016) study the moderating impact of brand awareness on the relationship with tourist motivation and the association of satisfaction and WOM. Product innovation is an essential signal of product improvement and availability and can therefore influence customer-purchasing behavior. Thus, the investigation on the moderating role of brand awareness on purchase intention will provide a better understanding of the centrality of brand awareness. Secondly, the investigation of brand awareness, especially the moderating role of brand awareness in the fashion industry in the Indonesian context, is very limited. A better understanding of the concept of brand awareness in a different context and culture may generate a different perspective affecting local business practitioners and scholars' ability to develop better, more suitable brand strategies to improve the customer experience (Shabbir et al., 2017). These gaps allow investigating further brand awareness and its moderating role in the triangle relationships between product innovation, brand trust, and brand loyalty in the Indonesian context.
To date, the simultaneous investigation on such relationships does not exist. Therefore, a detailed investigation from the Indonesian-specific perspective will provide a better understanding of this phenomenon and particularly help to answer the following research questions:

RQ1: Does brand awareness moderate the relationships between product innovation, brand trust, and brand loyalty?

RQ2: If so, which of these relationships are strongly moderated by brand awareness?

The structure of this study is presented in this following sequence. First, the literature review on brand loyalty, product innovation, and brand trust are discussed. Next, the discussion on this study's research methodology is presented. Subsequently, the findings of this study are elaborated, and finally, the study closes with the conclusion, research implications, limitations, and future research avenues.

\section{Literature Review}

\subsection{Indonesia, A New Economic Tiger in South East Asia}

Indonesia, the fourth most populous country globally, is the largest economy in Southeast Asia (Indonesia Investments, n.d.). Despite the impact of the global COVID-19 pandemic, University of Indonesian economists are confident that Indonesia could maintain economic growth of 5.0-5.2\% in 2020 (Kacaribu et al., 2020), and that growth is expected to increase to $5.6 \%$ in 2021 (Focus Economic, 2020). Mordor Intelligence (2020) suggests that one reason for this positive outlook is that the Indonesian retail sector remains one of the most promising sectors in the Asian region. In addition, Greenhouse (2019) suggests that the solid growth of e-commerce supports the Indonesian retail sector. Furthermore, independent international watchdogs reported that Indonesian retailers and manufacturers are creatively focused on innovation by finding new markets (Deloitte, 2015) and producing new products or services (McKinsey \& Company, 2016). Because of such a robust economic outlook, the U.S. government removed Indonesia from their "developing countries" list in January 2020 and now considers Indonesia as a new competitive and emerging economy in South East Asia (Iswara, 2020). Based on the degree of Indonesian businesses innovativeness and positive economic outlook, Indonesia is, therefore, the perfect consumer location to 
investigate the moderating effect of brand awareness in the Asian context.

\subsection{Brand Loyalty}

Nguyen et al. (2020) define brand loyalty as a customer's higher willingness to prioritize a specific brand over others regardless of other brands' efforts. Pribadi et al. (2019) suggest that multiple brand components determine customer brand loyalty. It includes brand experience, brand personality, and brand trust. Pribadi et al. (2019) found that a combination of such positive brand encounters improves customer willingness to stay and commit to the brand. When a customer perceives that the brand shares a similar personality and offers positive experiences, the customer tends to develop higher brand trust, which ultimately generates brand loyalty. Giovanis \& Athanasopoulou (2018) assert that brand loyalty serves as a company's indicator of customer faithfulness. That is, the more faithful the customer, the more they are open and willing to accept the brand's current and future performance (Herjanto et al., 2019; Kurniawan and Adiwijaya, 2018).

In support of the findings by Pribadi et al. (2019), Lam (2007) asserts that brand loyalty is a complex, multifaceted and challenging construct. To illustrate, Sinha et al. (2015) revealed that brand characteristics (brand trust, brand association, brand name, and brand preferences), perceptions (perceived quality, perceived value, and perceived risk), and product attributes are responsible for brand loyalty. In a different study, Khadim et al. (2018) documented those media communications, brand trust, and brand equity simultaneously affect brand loyalty. More recently, Adiwijaya et al. (2020) found that brand relationship quality and brand reputation determine brand loyalty. Although these findings show that scholars have paid a great deal of attention to the concept of brand loyalty (Chang \& Yang, 2008), these findings are still inconclusive (Casteran et al., 2019). According to Lam (2007), one reason for such mixed findings is that the extant literature has overlooked the impact of customer cultural components. Thus, to improve our understanding of the brand loyalty phenomenon, the current study extends the discussion by incorporating the moderating role of brand awareness on triangle relationships between product innovation and brand trust, product innovation and brand loyalty, as well as between brand trust and brand loyalty in the Indonesian fashion industry context.

\subsection{Product Innovation}

Traditionally, product innovation refers to a broad concept that includes any improvements, adjustments, and repositioned products (Chavez \& Zhao, 2015). However, in a modern perspective, product innovation is limited to totally new or significantly improved products that offer substantial modification in current technologies, methods, and ideas that cater to a new and current market (Lee et al., 2019). Conceptually, product innovation is designed to improve quality (Wu \& Wang, 2017), and for that reason, product innovation is challenging and complex (Yosifov \& Dmitrova, 2015). Consequently, product innovation has a high failure rate (Malgarejo \& Malek, 2018).

Despite this complexity, Nielsen (2015) suggests that $63 \%$ of customers are expecting product innovations, and 57\% of such customers claimed that they bought product innovation items. This data shows that a customer has a positive perception toward product innovation and views such products as a new and effective solution to their current issue (Cha et al., 2018). Accordingly, Edison et al. (2016) assert that product innovation offers competitive advantages that are crucial for businesses, and therefore, product innovation is known as one of the essential strategies to maintain business survival.

Operationally, Jiang et al. (2016) suggest that product innovation occurs based on two different types of thinking processes. The first process refers to exploitation product innovation. This process builds product innovation based on existing knowledge and expertise on the business opportunities and current situations. In contrast, the second process refers to the exploration of product innovation based on the curiosity to discover or develop a new solution to business opportunities and current situations. Further, the results of exploitation and exploratory products are classified into four categories based on their degree of improvement (Carayannopoulos, 2017). The first category is incremental innovation. This category involves small amendments or adjustments that do not change the basic structure and product function. The second category is architectural innovation. This category allows businesses to amend the basic structure of the product. 
Next is modular and radical innovation. Modular innovation changes the fundamental concept of the product, but it does not change the structure of the product. Finally, radical innovation changes the structure and the concept of the product. Regardless of the type of innovation, Lee et al. (2019) suggest that any of these improvements help solve customer problems. Because of the ability to solve customer issues, product innovation positively affects the brand (Hanaysha \& Hilman, 2015a). Having consistently positive experiences with a brand leads a customer to feel more comfortable and confident with future brand performance. Scholars suggest that when a customer experiences such situations, the customer's mental and cognitive state are filled with positive emotion, which eventually generates a higher satisfaction (Kim, 2005) and eliminates perceived risk and situation uncertainty (Chiu et al., 2010). Accordingly, Chinomona (2013) concludes that such a favorable situation improves customer trust in the brand. Based on this argument, we hypothesize that:

H1 : Product innovation has positive influences on brand trust.

As Lee et al. (2019) discussed earlier, product innovation is one way for the brand to address its customer problems. A customer views brand willingness and dedication to improving their living standard as a brand's genuine tendency to maintain the buyer-brand relationship (Hanaysha \& Hilman, 2015b). Lee and Soo (2012) suggest that when a customer has a high level of brand relationship, they are more willing to protect the brand. Thus, Gregoire et al. (2009) conclude that brand relationship quality refers to reflecting the customer's willingness to commit and stay in the relationship with the brand. Accordingly, Hanaysha \& Hilman (2015a) summarize that product innovation leads to brand loyalty. Thus, we hypothesize:

$\mathrm{H} 2$ : Product innovation has positive influences on brand loyalty.

\subsection{Brand Trust}

Herjanto et al. (2020) assert that brand trust is one of the most critical components in the concept of branding. It refers to a customer's high-quality expectation of a particular brand or product and service (Lake et al., 2019). During the decision-making process, a customer evaluates a product or service attribute (e.g., specification, weight) and judges the brand-related cues (e.g., logo, trademark, and brand image) as indicators of product quality. When a customer feels positive and confident with the product performance, the customer experiences lower anxiety and feels secure in their brand selection (Han et al., 2015) and higher brand trust (Lee et al., 2019). Hegner \& Jevons (2016) suggest that theoretically, the degree of brand trust is heavily reliant on four brand dimensions. They include (1) Brand competence or the degree of brands that offer the high-quality solution and solve a customer's problem adequately; (2) Brand predictability or brand consistency in delivering performance quality. A high level of brand predictability reduces anxiety while improving a feeling of security; (3) Brand benevolence or brand commitment to offering long-term quality performance. Hegner \& Jevons (2016) believe that brand benevolence serves as a true reflection of a brand's sincere concern for customer welfare. Finally, and (4) Brand integrity or the degree of ethical conduct in business performance. Scholars suggest that when a customer experiences a high level of brand trust, the customer simultaneously experiences higher brand satisfaction (Ercis et al., 2012; Kurniawan and Adiwijaya, 2018), which eventually generates higher brand attachment, commitment and ultimately brand loyalty (Ramaseshan \& Stein, 2014). Based on this discussion, we therefore hypothesize:

H3 : Brand trust has positive influences on brand loyalty.

\subsection{The Moderating Role of Brand Awareness}

Brand awareness refers to the degree of a brand's ability to establish strong appeal and presence in a customer's mind (Foroudi et al., 2018; Setiadi et al., 2018). A customer with higher brand awareness is more inclined to remember or distinguish the brand and associate it with its attributes (Anand, 2018; Wijaya et al., 2020). According to Kumar \& Arthi (2020), brand awareness serves as an essential gateway to the customer decision-making process because, without brand awareness, a customer does not understand or conscious that he or she has an option about this particular brand. Thus, the degree of brand awareness can strengthen brand positioning in the customer's consideration set and accordingly affect customer brand selection and decision-making (Phung et al., 2019; Wijaya et al., 2020; Setiadi et al., 2018). 
As discussed by Lee et al. (2019) earlier, product innovation serves as a brand's manifestation of genuine concerns of its customer welfare, as they produce new, improved products to meet customer needs. To fully appreciate such brand activities, Jian (2019) notes that firstly, a customer should have information about the product and associate it with existing knowledge in their memory. That means, during this information synchronization process, a customer will analyze whether product/brand information (i.e., new product attributes or functions) relevant to their extant knowledge (i.e., customer problems). If such brand information fits with the extant knowledge, the customer views the brand positively and ultimately improves brand trust. For example, if a customer views a new iPhone camera, information about new product innovation can improve the quality of their selfie pictures (extant problem), a customer will tend to perceive this new camera as a problem-solver, and accordingly, the customer experiences higher brand trust. Over time, when a customer consistently experiences positive new product performances, the customer would tend to have higher confidence in the brand, commitment, and ultimately, more willingness to continue the relationship and maintain brand loyalty. Based on this argument, we hypothesize:

H4 : Brand awareness moderates the relationship between product innovation and brand trust.

H5 : Brand awareness moderates the relationship between product innovation and brand loyalty.

Raza et al. (2019) suggest that buyer-brand relationships occur only if a customer is aware of the brand. That is, without brand awareness, the brand does not exist in the customer's mind. Therefore, the brand is not included in their decision-making alternatives. Thus, brand awareness serves as an initial component of any buyerbrand relationship. Radder \& Huang (2008) suggest that a higher level of brand awareness improves a customer-brand familiarity during this relationship-building process. The reason is, when a customer is aware of the product, his or her sensory organs can quickly identify brand attributes. For example, the customer could recognize the brand by seeing, hearing or thinking about it, and such abilities help the customer memorize the brand. According to Lee \& Rim (2017) and Dib \& Alhaddad (2014), high brand awareness and familiarity help build customer confidence and, thus, perceived quality. Further,
Homer (2006) suggests that continuous exposure to this perceived quality leads to a higher level of brand trust. Accordingly, we hypothesize:

H6 : Brand awareness moderates the relationship between brand trust and brand loyalty.

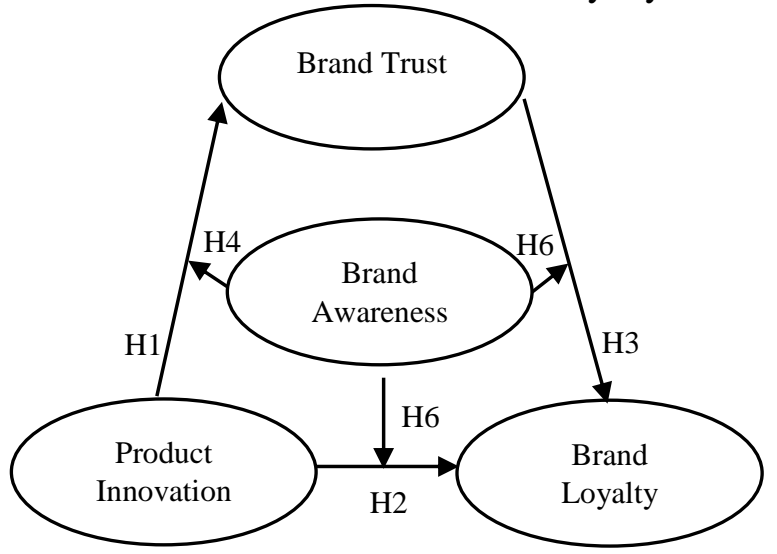

Figure 1. The Centrality of Brand Awareness model

\section{Methods and Data Analysis}

\section{a. Sample and data collection}

An online survey was conducted to gather data to confirm the hypotheses of the present study. This research selected the Indonesian fashion industry as it is very competitive and innovative and because young Indonesians are becoming increasingly fashionable. As this study seeks to understand the moderating effects of brand awareness between product innovation relationships and brand trust and brand loyalty, the researchers selected an Indonesian fashion brand " $Z$ " as our research setting. The brand " $Z$ " is considered an innovative brand. At the beginning of the online survey, participants were presented with a screening question asking whether they are aware of brand " $Z$ ". This screening question is vital in confirming their suitability and the quality of data gathered. Participants who had never known brand " $Z$ " were omitted. Participants answered this screening question by selecting yes or no from the drop-down list, followed by the remainder of the questions.

Table 1. A Brief Overview of Participants' Characteristics

\begin{tabular}{lccc}
\hline Characteristics & $\begin{array}{c}\text { Frequency } \\
(\%)\end{array}$ & Characteristics & $\begin{array}{c}\text { Frequency } \\
(\%)\end{array}$ \\
\hline $\begin{array}{l}\text { Gender } \\
\text { Male }\end{array}$ & $43(43)$ & Female & $57(57)$ \\
\hline Occupation & & Age & \\
Self-Employed & $24(24)$ & $20-30$ & $69(69)$ \\
Full-time & $52(52)$ & $31-40$ & $8(8)$ \\
employed & $15(15)$ & $41-50$ & $16(16)$ \\
Housewife & $9(9)$ & $>50$ & $7(7)$ \\
Student & & &
\end{tabular}


In order to collect enough participant responses, the researchers developed and published the online survey on the university's student standard website. According to $\mathrm{Hu}$, Yan, An, Guo, \& Qian (2019), an online survey is suitable for this study because an online survey is easy and straightforward to answer. A total of 100 questionnaires were fully completed and usable. Table 1 presents a brief overview of participants' characteristics.

\section{b. Measurements}

Adopted and transformed scales from the published literature measured four constructs in this particular study. For example, Rogers' (2003) multiple item scale, measuring product innovation, was borrowed and adjusted, whereas Kim, Morris \& Swait's (2008) items that measure brand loyalty were employed and modified to fit with this present study. Finally, multiple items of brand awareness and brand trust were used by Cifci et al. (2016), and Koschate-Fischer \& Gartner (2015) were borrowed with some amendments. Five-point Likert scales anchored at strongly agree to strongly disagree were employed. This research followed Ward et al. (2018) double translation process recommendation to safeguard the correct translation from English to Indonesian and vice versa. Firstly, the entirely adopted scales were translated to the Indonesian language by one of the authors. The second author then translated it back to English. The translated scale was compared with the original, and the result was discussed. In order to ensure consistency and accuracy.

The validity of each scale was tested by a varimax factor ratio and a principal component analysis with Eigenvalue $>1$. In addition, a minimum value of 0.45 was employed to identify factor loadings. The Cronbach alpha for brand loyalty, brand awareness, and brand trust were all strong except for purchase intention. The Cronbach alpha for purchase intention was 0.59 , less than the standard consensus score of 0.7. Scholars suggest that although the score of the Cronbach alpha 0.59 was lower than the standard consensus score of 0.7 , this score is within the 0.58-0.95 range, which is acceptable (Jezewski et al., 2005; White et al., 2012; Sabag \& Trotskovsky, 2016), and considered to be moderate reliability (Perkins-Porras et al., 2018). Table 2 shows the psychometric property of the present study.
Table 2. Psychometric Property of the Present Research

\begin{tabular}{lccc}
\hline \multicolumn{1}{c}{ Items } & Mean & $\lambda$ & $\alpha$ \\
\hline $\begin{array}{l}\text { Product Innovation } \\
\text { I can use a product innovation } \\
\text { of brand Z easily }\end{array}$ & 4.13 & 0.938 & 0.590 \\
$\begin{array}{l}\text { I can easily follow the } \\
\text { instruction of a product }\end{array}$ & 4.39 & 0,489 & \\
innovation of brand Z & & & \\
\hline $\begin{array}{l}\text { Brand loyalty } \\
\text { I choose a brand Z as my } \\
\text { primary choice }\end{array}$ & 4.00 & 0,737 & 0.808 \\
I will rebuy a brand Z & 3.81 & 0,846 & \\
\hline $\begin{array}{l}\text { Brand awareness } \\
\text { I am aware of brand Z }\end{array}$ & 4.03 & 0,619 & 0.814 \\
$\begin{array}{l}\text { I can distinguish brand Z from } \\
\text { other brands }\end{array}$ & 4.02 & 0,909 & \\
I remember brand Z & 4.02 & 0,664 & \\
\hline $\begin{array}{l}\text { Brand trust } \\
\text { I trust the quality of brand Z }\end{array}$ & 4.14 & 0,805 & 0.893 \\
$\begin{array}{l}\text { I trust the performance of } \\
\text { brand Z }\end{array}$ & 4.19 & 0,822 & \\
$\begin{array}{l}\text { I am sure that brand Z fulfils } \\
\text { my needs }\end{array}$ & 4.27 & 0,832 & \\
\hline Notes: $\lambda=$ factor loadings and $\alpha=$ Cronbach alpha scores \\
\hline
\end{tabular}

\section{Results and Discussion}

Ordinary Least Square (OLS) regression was used to test our hypotheses, while Baron \& Kenny's (1986) procedure tested the moderator hypotheses. The OLS regression tests revealed that product innovation is positively responsible for brand trust $(B=.601, \mathrm{p}<.001)$ and brand loyalty $(\beta=.765, \mathrm{p}<.001)$. The findings can be translated that product innovation serves as the main ingredient of brand success. In today's busy life, a customer has a very busy schedule (Myhal et al., 2008) and therefore has no time to deal with poor product performance (Banati, 2011). Failure to buy a good quality product leads to financial losses, inconvenience (Yeh \& Lo, 2001), and emotional discomfort (Bonifield \& Cole, 2007). According to product innovation theory, product innovation is not a one-off process but an ongoing company effort to consolidate their expertise, resources, and opportunities to help reduce customer inconvenience while improving their living standard (Cormican \& O'Sullivan, 2004). To a customer, a product innovation not only serves as a tool to solve their problem, but it also serves as a differentiator among other brands. Oftentimes, a customer faces many alternatives during the brand selection process and experiences uncertainty and risks (Herjanto, Gaur \& Hong, 2017). The newly invented attributes clarify the customer brand-selection process by 
reducing customer ambiguity through design, purpose, and major functionality. For example, a check-depositing app from Bank of America distinguishes itself from its banking competitors, and it helps to improve customer appreciation. This example shows that such innovation not only enhances appreciation but, more importantly, it translates as the bank's commitment to customers, which ultimately improves customer-brand trust.

Further, the present research also confirmed that product innovation generates a higher level of brand loyalty. Some possible explanations for this finding could be; first, product innovation improves the emotional and status state of the customer. For example, product innovation usually is more expensive, and therefore, a customer who uses product innovations may feel good about themselves and more prestigious. This good feeling is addicting, as the customer feels the brand helps him/her to lift their status. Therefore, to maintain such positive feelings, a customer tends to maintain their brand loyalty. Second, generally, product innovation offers better performance. This performance improvement creates a higher level of comfort and convenience. Thus, to maintain this favorable situation, a customer may be more inclined to stay loyal to the brand. The findings of this research confirmed Nemati et al. (2010), who found this relationship in Pakistan's mobile phone context. Thus, $\mathrm{H} 1$ and $\mathrm{H} 2$ were supported.

The present study's findings also validate that brand trust positively and significantly influences brand loyalty $(B=.821, \mathrm{p}<.001)$. The classic trust theory suggests that brand trust is a fundamental ingredient to fruitful relationships and relationship longevity (Levin et al., 2016). To a customer, the degree of brand trust reflects a customer's positive perception toward consistent brand quality performance, and more importantly, it indicates the company's ability to offer a high level of security to their customer. When a customer experiences high brand trust, he or she tends to experience peace of mind. Accordingly, it reduces customer perceived risk and therefore cements customer reliance on the brand.
Ultimately, the customer feels that a brand will not betray them, and consequently, this leads to a higher tendency to stay loyal to the brand.

This study supports the findings of Pribadi et al. (2019), who also revealed that brand trust generates higher brand loyalty. Thus, H3 was also supported.

The results of OLS regression also shows that brand awareness moderates the triangle relationships between product innovation and brand trust $(\beta=.102, p<.001)$, product innovation and brand loyalty $(\beta=.133, \mathrm{p}<.001)$, and brand trust and brand loyalty $(\beta=.122, \mathrm{p}<$ $.001)$. In general, these findings demonstrate the centrality of brand awareness in such relationships. In other words, to enhance the attractiveness of product innovation and brand trust, a brand should ensure a customer has a high level of brand awareness. According to Keller et al.'s (2003) brand awareness theory, brand awareness is a true reflection of a customer's ability to recognize a brand. That is, in any circumstance or situation, a customer can easily identify such a brand without any difficulty. The high level of such brand familiarity will help a customer to compare and identify newly invented attributes or functions easily. As a result, brand awareness improves product innovation attractiveness. Thus, when a customer identifies such new attributes, a customer feels that the brand is committed to supporting and improving the customer's living standard. Accordingly, it improves the degree of trustworthiness toward the brand and commitment to maintaining their relationship with the brand. Therefore, $\mathrm{H} 4$ and $\mathrm{H} 5$ were confirmed.

Herjanto et al., (2019) customer faithfulness theory could explain the moderating effect of brand awareness on the relationship between brand trust and brand loyalty. According to Herjanto et al. (2019), customer faithfulness or a high level of loyalty is an ultimate product of a high level of customer commitment. During the customer-faithfulness building process, Herjanto et al. (2019) suggest that a customer should be aware that a brand could satisfy their needs.

Table 3. Summary of the Hypotheses Testing

\begin{tabular}{|c|c|c|c|c|c|c|}
\hline \multicolumn{2}{|r|}{ Hypotheses } & $\mathrm{F}$ & $\mathrm{R}^{2}$ & $\beta$ & $\mathrm{P}$ & Results \\
\hline H1 & Product Innovation $\rightarrow$ Brand trust & 43.551 & .310 & .601 & $<0.001 * * *$ & Supported \\
\hline $\mathrm{H} 2$ & Product Innvoation $\rightarrow$ Brand loyalty & 42.759 & .306 & .765 & $<0.001 * * *$ & Supported \\
\hline $\mathrm{H} 3$ & Brand trust $\rightarrow$ Brand loyalty & 67.819 & .411 & .821 & $<0.001 * * *$ & Supported \\
\hline $\mathrm{H} 4$ & BAwareXPInovation $\rightarrow$ Brand trust & 97.000 & .500 & .102 & $<0.001 * * *$ & Supported \\
\hline H5 & BAwareXPInovation $\rightarrow$ Brand loyalty & 102.174 & .508 & .133 & $<0.001 * * *$ & Supported \\
\hline H6 & BAwareXBTrust $\rightarrow$ Brand loyalty & 103.118 & .515 & .122 & $<0.001 * * *$ & Supported \\
\hline
\end{tabular}


Accordingly, this high level of awareness helps a customer evaluate such benefits, which generates higher brand trust (Civelek \& Ertemel, 2018) and brand loyalty. To illustrate, during the decisionmaking process, a customer tends to select a familiar brand because familiarity reduces perceived risk, and at the same time, improves brand trust and enhances brand loyalty. Thus, H6 was supported. Table 3 shows a brief overview of the results of tested hypotheses.

\section{Conclusion}

The present study confirmed a direct effect of product innovation on brand trust and brand loyalty, and a direct effect of brand trust on brand loyalty. In addition, the study validated the centrality of brand awareness by testing its moderating effect on triangle relationships between product innovation and brand trust, product innovation and brand loyalty, brand trust, and brand loyalty. In sum, these findings show that to improve the degree of attractiveness of product innovativeness and brand trust, a brand should firstly improve brand awareness. Without a high degree of brand awareness, a customer may not know the differentiators of the product innovation resulting in a less attractive perception. Therefore, the customer may have less confidence in the brand, affecting brand trust negatively, or the customer may also have no reason to uphold a relationship with the brand, which ultimately reduces brand loyalty. This study extends the understanding of the brand phenomenon by simultaneously testing brand awareness in these triangle relationships.

\section{Implications, Limitations, and Future Research Avenues}

The findings of this study establish some critical implications for business practitioners, especially fashion businesses, and academics to consider. For fashion business practitioners, this study recommends that businesses build strong brand awareness before they further pursue their business endeavors. The study also shows that brand loyalty is not a single facet but rather challenging and multifaceted. Therefore, businesses should consider brand loyalty in a 360 -degree view rather than a narrow, singlesided view. This present study extends branding theory by showing the centrality of brand awareness's moderating effects on academics. Only a handful of studies investigated the moderating effect of brand awareness simultaneously, especially in the relationships between product innovation, brand trust, and brand loyalty.

Like any research project, this study experienced several caveats, which could be extended in the future. First, the number of respondents was limited, and therefore, the findings may not reflect the typical Indonesian customer. Second, this research also gathered its data from a university student portal, and therefore, the diversity of participants is limited to that website's community. Thirdly, the findings may not apply to other countries and regions or it may be oversimplified. Furthermore, future research should extend the model by employing different variables and test the mediating effect similarly.

\section{References}

Adiwijaya, M., Herjanto, H., Soeryadi, A., \& Subagio, A. (2020). The Moderating Effect of Switching Costs on The Brand Loyalty. Paper presented at I-Come Conference July 23-35(postponed), Sarawak, Malaysia.

Anand, N.V. (2018). Measurement of Brand Awareness and Brand Perception of Automobile Company. International Journal of Research in Mechatronics \& Automobile Engineering, 5(2), 42-50.

Banati, D. (2011). Consumer Response to Food Scandals and Scares. Trends in Foods Science and Technology, 22(2/3), 56-60.

Baron, R.M., \& Kenny, D.A. (1986). The Moderator-Mediator Variable Distinctions in Social Psychological Research: Conceptual, Strategic and Statistical Consideration, Journal of Personality and Social Psychology, 51(6), 1173-1182.

Bonifield, C., \& Cole, C. (2007). Affective Responses to Service Failure: Anger, Regret and Retaliatory Versus Conciliatory Responses. Marketing Letters, 18, 85-99.

Carayannopoulos, S. (2017). Small, Young Firm Flexibility and Performance in The Context of Disruptive Innovations. International Journal of Entrepreneurship and Innovation Management, 21(1/2), 105-118.

Casteran, G., Chrysochou, P., \& MeyerWaarden, L. (2019). Brand Loyalty Evolution and The Impact of Category Characteristics. Marketing Letters, 30, 5773.

Cha, J.M., Kim, S.H., \& Singh, A.J. (2018). Adoption of A Wellness Product in The 
Hotel. Paper presented at $8^{\text {th }}$ Advances in Hospitality and Tourism and Management Conference, June 25-29, 2018. Bangkok, Thailand.

Chang, H.L., \& Yang, C. H. (2008). Explore Airlines' Brand Niches Through Measuring Passengers' Repurchase Motivation - An Application of Rasch Measurement. Journal of Air Transport Management, 14, 105-112.

Chavez, F.N.V., \& Zhao, Y.L. (2015). Innovation in The Enterprise: Market Orientation As An Important Factor Towards Product Innovation. International Journal of Management Science and Business Administration, 1(11), 21-33.

Chinomona, R. (2013). The Influence of Brand Experience on Brand Satisfaction, Trust and Attachment in South Africa. International Business \& Economics Research Journal, 12(10), 1303-1316.

Chiu, C. M., Huang, H. Y., \& Yen, C. H. (2010). Antecedents of Online Trust in Online Auctions. Electronic Commerce Research and Application, 9, 148-159.

Cifci, S., Ekinci, Y., Whaytt, G., Japutra, A., Molinillo, S., \& Siala, H. (2016). A Cross Validation of Consumer-Based Brand Equity Models: Driving Customer Equity in Retail Brands. Journal of Business Research, 69(9), 3740-3747.

Civelek, M., \& Ertemel. A. (2018). Trust Building Model of Customers on B2C Websites: A Research on Generation Y Customers. Journal of History Culture and Art Research, 7(1), 332-340.

Deloitte. (2015). UKM Pemicu Kemajuan Indonesia. Retrieved from www2.deloitte. com/content/dam/Deloitte/id/Documents/fi nance/id-fas-sme-powering-indonesiasuccess-report-bahasa-noexp.pdf.

Dib, H., \& Alhaddad, A. (2014). The Hierarchical Relationships Between Brand Equity Dimensions. European Scientific Journal, 10(28), 183-194.

Edison, H., Wang, X., \& Abrahamsson, P. (2016). Product Innovation Through Internal Startup in Large Software Companies: A Case Study. Paper is presented at 42th Euromicro Conference on Software Engineering and Advanced Applications, Aug 2016, Limassol, Cyprus.

Ercis, A., Unal, S., Candan, F. B. \& Yildrim, H. (2012). The Effect of Brand Satisfaction, Trust and Brand Commitment on Loyalty and Repurchase Intentions. Procedia-Social and Behavioral Sciences, 58, 1395-1404.

Focus Economics. (2020). Indonesia Economic Outlook. Retrieved from https://www.focuseconomics.com/countries/indonesia.

Foroudi, P., Jin, Z., Gupta, S., Foroudi, M.M., \& Kitchen, P.J. (2018). Perceptional Components of Brand Equity: Configuring The Symmetrical and Asymmetrical Paths to Brand Loyalty and Brand Purchase Intention. Journal of Business Research, 89, 462-474.

Freixanet, J., \& Churakova, I. (2018). Exploring The Relationship Between Internationalization Stage, Innovation, and Performance. The case of Spanish companies. International Journal of Business, 23(2), 131150.

Giovanis, A. N., \& Athanasopoulou, P. (2018). Consumer-Brand Relationships and Brand Loyalty in Technology-Mediated Services. Journal of Retailing and Consumer Services, 40, 287-294.

Greenhouse. (2020). Indonesia's Digital Economy: Growth Prospects After 2020. Retrieved from greenhouse.co/blog/ indonesia-digital-economy-prospects-after2020/

Hagner, S. M., \& Jevons, C. (2016). Brand Trust: A Cross-National Validation in Germany, India and South Africa. Journal of Product \& Brand Management, 25(1), 5868.

Han, S.H., Nguyen, B. \& Lee, T. J. (2015). Consumer Based Chain Restaurant Brand Equity, Brand Reputation and Brand Trust. International Journal of Hospitality Management, 50, 84-93.

Hanaysha, J., \& Hilman, H. (2015a). The Impact of Product Innovation on Relationship Quality in Automotive Industry: Strategic Focus on Brand Satisfaction, Brand Trust and Brand Commitment. Asian Social Science, 11(10), 94-104.

Hanaysha, J., \& Hilman, H. (2015b). Strategic Effects of Product Innovation, Service Quality and Relationship Quality on Brand Equity. Asian Social Science, 11(10), 56-72.

He, X., Liu, B., \& Li, S. (2017). Reflections on The Teaching of Packaging Design Based on Brand Strategy. Advances in Social Science, Education and Humanities Research, 95, 40-43. 
Herjanto, H., Gaur, S.S, \& Hong, J.H.H. (2017). Factors Influencing Consumers' Purchase Intention of Genuine Products and Intention to Use Pirated Products: Malaysian Perspective. Paper presented at International Conference on Management and Entrepreneurship (I-Come), July 13-15, Bali, Indonesia.

Herjanto, H., Scheller-Sampson, J., \& Andreani, F. (2019). Customer Faithfulness: The Moderating Role of The Relational Benefits Trilogy. Paper presented at Marketing Management Association Spring Conference, March 27-29, Chicago, U.S.A.

Herjanto, H., Adiwijaya, M., Wijaya, E., \& Semuel, H. (2020). The Effect of Celebrity Endorsement on Instagram Fashion Purchase Intention: The Evidence from Indonesia. Organizations and Markets in Emerging Economies, 11(1), 203-221.

Homer, M.P. (2006). Relationships Among AdInduced Affect, Beliefs and Attitudes: Another Look. Journal of Advertising, 35(1), 35-52.

Hu, S., Yan, D., An, J., Guo, S., \& Qian, M. (2019). Investigation and Analysis of Chinese Residential Building Occupancy with Large Scale Questionnaire Surveys. Energy and Building, 193, 289-304.

Indonesia Investments. (n.d.). Economy of Indonesia. Retrieved from www.indonesiainvestments.com/culture/economy/item 177 .

Iswara, M.A. (2020). Revocation of Indonesia's Developing Country Status Will Not Affect GSP: Government. Retrieved from https://www.thejakartapost.com/news/2020/ 02/25/revocation-of-indonesias-developingcountry-status-will-not-affect-gspgovernment.html.

Jezewski, M.A., Brown, J.K., Wu, Y.W.B., Meeker, M.A., Feng, J.Y., \& Bu, X. (2005). Oncology Nurses' Knowledge, Attitudes, and Experiences Regarding Advance Directives. Oncology Nursing Forum, 32(2), 319-327.

Jian, Z. (2019). Research on Enterprise Brand Equity Evaluation Based on Cognitive Psychology. Paper presented at AMME 2019 Conference, Kuala Lumpur, Malaysia, pp. 1-6.

Jiang, W., Liu, Y., Wu, Y., \& Cai, S. (2016). Integrative Capability, Product Innovation, and The Moderating Role Of Proactiveness and Technological Environment. 2016 Proceeding of PICMET'16: Technology
Management for Social Innovation, 24672475.

Kacaribu, F.N., Sabrina, S., Desdiani, N.A., \& Riefky, T. (2020). Indonesia Economic Outlook 2020. Retrieved from www.lpem.org/wp-content/uploads/2019/ 11/Indonesia-Economic-Outlook-2020.pdf

Keller, K. L., Paameswaran, M.G. \& Jacob. I. (2003). Strategic Brand Management: Building, Measuring and Managing Brand Equity. Pearson Education. India.

Khadim, A.R., Hanan, M.A., Arshad, A., Saleem, N., \& Khadim, A.N. (2018). Revisiting Antecedents of Brand Loyalty: Impact of Perceived Social Media Communication with Brand Trust and Brand Equity as Mediators. Academy of Strategic Management Journal, 17(1), 1-14.

Kim, H. (2005). Consumer Profiles of Apparel Product Involvement and Values. Journal of Fashion Marketing and Management, 9, 207-220.

Kim, J. Morris, J.D., \& Swait, J. (2008). Antecedents of True Brand Loyalty. Journal of Advertising, 37(2), 99-117.

Koschate-Fischer, N., \& Gartner, S. (2015). Brand Trust: Scale Development and Validation. Schmalenbach Business Review, 67, 171-195.

Kumar, S.L., \& Arthi, R. (2020). A Study on Brand Awareness of Oneplus with Special Reference to Coimbatore District, Tamilnadu. Mukt Shadb Journal, 9(4), 718727.

Kurniawan, F.A., and Adiwijaya, W. (2018). The Analysis of Online Brand Community, Online Perceived Brand Reputation, Brand Trust, Brand Loyalty at Cafe Businesses Based in Surabaya. International Journal of Business Studies, 1(1), 11-22, doi: https://doi.org/10.9744/ijbs.1.1.11-22

Lake, C.J., Carlson, J., Rose, A. \& ChlevinThiele, C. (2019). Trust in Name Brand Assessments: The Case of The MyersBriggs Type Indicator. The PsychologistManager Journal, 22(2), 91-107.

Lam, D. (2007). Cultural Influence on Proneness to Brand Loyalty. Journal of International Consumer Marketing, 19(3), 7-21.

Lee, J. (2018). Factor Analysis on Brand Recognition and Image Purchases. Journal of Research in Marketing, 9(2), 723-732.

Lee, J., \& Rim, H. (2017). Consumer Evaluation of Cause Brand Alliance in 
Cause Related Advertising: The Role of Brand Familiarity and Personal Relevance. Business Management and Strategy, 8(1), 103-122.

Lee, R., Lee, J.H., \& Garrett, T.C. (2019). Synergy Effects of Innovation on Firm Performance. Journal of Business Research, 99, 1-9.

Lemmetyinen, A., Dimitrovski, D., Nieminen, L., \& Pohjola, T. (2016). Cruise Destination Brand Awareness as A Moderator in Motivation Satisfaction Relation. Tourism Review, 71(4), 245-258.

Levin, E., Thaichon, P., \& Qucah, T.N. (2016). The Impact of Creative Competence and Project Management on Longevity of The Client Advertising Agency Relationship. Journal of Business \& Industrial Marketing, 31(2), 274-286.

Liu H.W., Huang HC. (2015). Tradeoff Between Push and Pull Strategy: The Moderating Role of Brand Awareness. In: Spotts H. (Eds) Marketing, Technology and Customer Commitment in the New Economy. Developments in Marketing Science: Proceedings of the Academy of Marketing Science. Springer, Cham, pp. 259-264.

McKinsey \& Company. (2016). Unlocking Indonesia's digital opportunity. Retrieved from www.mckinsey.com/ /media/Mc Kinsey/Locations/Asia/Indonesia/Our\%20I nsights/Unlocking\%20Indonesias\%20digita 1\%20opportunity/Unlocking_Indonesias_di gital_opportunity.ashx

Melgarejo, R., \& Malek, K. (2018). Setting the Record Straight on Innovation Failure. Retrieved from www.nielsen.com/wpcontent/uploads/sites/3/2019/04/setting-therecord-straight-common-causes-ofinnovation-failure-1.pdf

Minh, L.P.T., Ju, T.L., Liao, Y.K., \& Wu, W.Y. (2015). The Influences of Experiential, Cognitive and Marketing Factors on Brand Personality and Brand Equity. Paper presented at $9^{\text {th }}$ International Conference on Management, Marketing and Finances, September 5-7, 2015, Seoul, South Korea.

Mordor Intelligence (2020). Indonesia retail sector-growth, trends and forecast (20202025). Retrieved www.mordorintelligence. com/industry-reports/indonesian-retailindustry

Morin, C. (2020). Winning The Innovation Game with Jobs to be Done Theory.
Retrieved from crm.org/articles/jobs-to-bedone-theory

Myhal, G.C., Kang, J., \& Murphy, J.A. (2008). Retaining Customers Through Relationship Quality: A Service Business Marketing Case. The Journal of Services Marketing, 22(6), 445-453.

Nemati, A.R., Khan, K., \& Iftikhar, M. (2010). Impact of Innovation on Customer Satisfaction and Brand Loyalty, A Study of Mobile Phones Users in Pakistan. European Journal of Social Sciences, 16(2), 299-306.

Nguyen, M.N., Duong, H.H., Nguyen, T.H., Pham, T.H.N., \& Nguyen, T.T.P. (2020). Mediating Effect of Social-Commerce Continuance Use Intention on The Relationship Between Perceived Values and Brand Loyalty. European Journal of Business and Management, 12(11), 58-65.

Nielsen. (2015). Looking to Achieve New Product Success? Retrieved from www.nielsen.com/wpcontent/uploads/sites/ 3/2019/04/nielsen-global-new-productinnovation-report-june-2015.pdf

Perkins-Porras, L., Whitehead, D.L., Strike, P.C., \& Steptoe, A. (2018). Causal Beliefs, Cardiac Denial and Pre-Hospital Delays Following The Onset of Acute Coronary Syndromes. Journal of Behavioral Medicine, 31, 498-505.

Phung, M.T., Ly, P.T.M., \& Nguyen, T.T. (2019). The Effect of Authenticity Perceptions and Brand Equity on Brand Choice Intention. Journal of Business Research, 101, 726-736.

Pribadi, A. P., Adiwijaya, M., \& Herjanto, H. (2019). The Effect of Brand Trilogy on Cosmetic Brand Loyalty, International Journal of Business Society, 20(2), 730-742.

Puspitasari, A.F., \& Dwijayanti, I.S. (2019). Evaluation Analysis of Airlangga University Faculty of Vocational Education's Brand Equity Using Customer Based Brand Equity Concept. The International Journal of Applied Business, 1(1), 33-46.

Putra, R.P., \& Razi, A.A. (2020). Value Proposition of Instagrammable Digital Tourism in Forming Brand Identity. Advances in Social Science, Education and Humanities Research, 409, 163-166.

Raimondo, M.A., Vernuccio, M., \& Miceli, G.N. (2019). The Effects of Native Advertising on Consumer Responses. Some Experimental Evidence on The Interaction 
Between Content Type and Brand Awareness. Mercati \& Competitivita, 3, 149-168.

Rajak, N., Themba, O.S., \& Sjahruddin, H. (2019). Brand Awareness as Predictors of Repurchase Intention: Brand Attitude as A Moderator. Advances in Social Science Research Journal, 6(2), 541-554.

Ramaseshan, B., \& Stein, A. (2014). Connecting The Dots Between Brand Experience and Brand Loyalty: The Mediating Role of Brand Personality and Brand Relationships. Journal of Brand Management, 21(7/8), 64-683.

Rauschnabel, P.A., \& Ahuvia, A.C. (2014). You're So Lovable: Anthropomorphism and Brand Love. Journal of Brand Management, 21(5), 372-395.

Raza, M., Salleh, S.M., \& Saari, H. (2019). Role of Brand Awareness, Brand Loyalty and Customer Citizenship Behavior in Aviation Sector of Pakistan. International Journal on Economics, Finance and Sustainable Development, 1(2), 39-41.

Rogers, E. M. (2003). Diffusion of Innovation $\left(5^{\text {th }} \mathrm{Ed}\right)$. New York: Free Press.

Sabag, N., \& Trotskovsky, E. (2015). An Examination of The Relationship Between Instructional Strategies to Learning Styles Distance and Students' Achievements. International Journal of engineering Education, 32(5A), 1903-1910.

Setiadi, E., Adiwijaya, W. and Subagio, H. (2018). The Impact of Brand Awareness and Country of Origin on Purchase Intention with Mediation of Self Congruity on Chinese Brand Automotive Products Wuling. International Journal of Business Studies, 1(2), 70-79, https://doi.org/10.9744 lijbs. 1.2.70-79

Shabbir, M.Q., Khan, A.A., \& Khan, S.R. (2017). Brand Loyalty, Brand Image and Brand Equity: The Mediating Role of Brand Awareness. International Journal of Innovation and Applied Studies, 19(2), 416423.

Shin, J., Kim, Y., Yang, H., \& Kim, C. (2019). What is the Right Innovation Type for Your Industry? Evidence from Chemical Firms in Korea. Process, 7(643), 1-16.

Sinha, K., Khajuria, R., \& Thakar, H. (2015). Understanding The Antecedents of Brand Loyalty for Improved Brand Sustainability. Studies \& Proceedings of Polish Association for Knowledge Management, 89, 5-19.
Stebbins, S. (2020). Biggest Product Launches of The Year. Retrieved from 247wallst.com/ special-report/2019/12/20/ biggest-productlaunches-of-the-year/

The Editorial Board. (2019). Andrew Yang: Businessman from New York. Retrieved from www.nytimes.com/interactive/2020/ 01/15/opinion/andrew-yang-nytimesinterview.html

Uribe-Saavedra, F., Llonch-Andreu, J., \& Rialp-Criado, J. (2015). The Effect of Online Comments on Buying Intention and Brand Trust: The Moderating Role of Brand Awareness and Type of Product. Paper presented at World Marketing Congress Academy of marketing Science, Bari, Italy.

Vasudevan, S., \& Kumar, F.J.P. (2019). Changing Realty: Altering Paths of Brand Discovery for Real Estate Websites in India. Property Management, 37(3), 346-366.

Wang, X., \& Yang, Z. (2010). The Effect of Brand Credibility on Consumers' Brand Purchase Intention in Emerging Economies: The Moderating Role of Brand Awareness and Brand Image, Journal of Global Marketing, 23, 177-188.

Ward, A.L., Wyeth, E. H., McGee, R., Freeman, C., \& Cameron, C. (2018). Found In (Survey) Translation: Lessons Learned While Engaging with Wharekura in Southland, New Zealand. Kotuitui: New Zealand Journal of Social Sciences Online, 13(1), 70-81.

White, G., Cordato, D., O’Rourke, F., Mendis, R., Ghia, D., \& Chan, D. (2012). Validation of The Stroke Rehabilitation Motivation Scale: A Pilot Study. Asian Journal of Gerontology \& Geriatrics, 7, 80-87.

Wijaya, L.S., Vanel, Z. Huwae, G.N., and Kristanto, B. (2020). Socialization As Integrated Marketing Communication Strategy In Increasing Brand Awareness (Case Study "Solo Destination" Application Of Solo City Government). International Journal of Business Studies, 3(1), 54-63.

Wu, A., \& Cassandra, W. (2017). Knowledge Search Pattern and Product Innovation of Firms in Low \& High-Technology Industrial Clusters: A Knowledge Relatedness Perspective. Journal of Economic \& Social Geography, 108(4), 488-502.

Yeh, R.H, \& Lo, H.C. (2001). Optimal Preventive Maintenance Warranty Policy for Repairable Products. European Journal of Operational Research, 134(1), 59-69. 
Yigit, M.K., \& Tigli, M. (2018). The Moderator Role of Brand Awareness and Brand Loyalty on Consumers' Online Impulse Buying Behavior. Research in Business and Social Science, 7(1), 35-48.
Yosifov, T., \& Dimitrova, T. (2015). The Banking Sector Product Innovations Gearing Factors for Customer Confidence. Trakia Journal of Sciences, 13(1), 362-367. 